\title{
微小石灰化陰影像の形状解析による マンモグラフィ用フィルムの延長現像の検討
}

\author{
丸山敏則・山本秀樹 ${ }^{11}$ \\ 岡山大学医学部保健学科 \\ 1 ) 岡山大学教育学部
}

緒 言

わが国では乳がんの早期発見のために，視触診とX 線乳房撮影(以下マンモグラフィ)との併用検診が導入 されている．しかし，マンモグラフィの導入率は5割 にとどまり，厚生労働省はマンモグラフィの全面導入 へと見直しを検討し，さらに対象年齢を50歳以上から 40歳以上に引き下げるよう提言した ${ }^{1,2)} . X$ X線被曝を 低減し，かつ高画質て診断に有用な写真を得ることが ますます重要な課題となる .

この課題に対して，われわれはマンモグラフィにお いて，低線量X線照射されたフィルムに現像時間を延 長したextended process(以下延長現像)を行い，でき るかぎり高画質の写真を得る方法について提案してき た ${ }^{3)}$.ファントム実験によって，34ㄷ，210秒の延長
現像における微小石灰化陰影像 (以下微小陰影像)の濃 度プロファイルはフィルム製造会社の推奨である $34^{\circ} \mathrm{C}$, 90秒の標準現像処理を行った写真と顕著な差は なく，被曝を低減できることを確認した ${ }^{3)}$ 。しかし， 少ない線量による延長現像処理力微小陰影像の形状に 及ぼす影響については検討していない．

そこで，本研究では，画質をより正確に評価するた めに, 微小陰影像の形状に着目して, ディジタル画像 処理による領域分割を行い，微小陰影像を抽出し，形 状を計測する方法を提案する . ファントム実験におい て，低線量X線照射したフィルムに150秒，210秒の延 長現像処理，高線量X線照射したフィルムに90秒の標

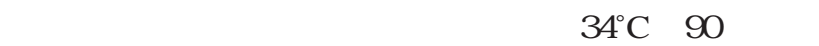
準現像処理を行った写真とほぼ同程度の画質を保持す

Study of the Extended Process for Mammographic Film with T wo-dimensional Shape A naly sis of Micr o-calcifications

TOSHINORI MARUYAMA, and HIDEKI YAMAMOTO ${ }^{1)}$

Faculty of Health Sciences, Okayama University Medical School

1 ) Faculty of Education, Okayama University

Received June 3, 2005; Revision accepted Nov. 14, 2005; Code No. 531

\section{Summary}

This paper describes the extended development process(extended process)that compensates for the image quality of mammographic film exposed at a lower radiation dose. First, we developed films exposed to a phantom with several small particles that simulated micro-calcifications at high and lower radiation doses, respectively. Next, we eval uated the image quality of those films developed for the standard development time of 90 seconds, and for the extended development times of 150 seconds and 210 seconds. Then we extracted micro-calcification regions and calculated the areas, perimeters, and normalized areas of micro-calcifications by using image analysis. There was no significant difference in areas or shape measurements between the development times of 90 seconds and 150 seconds in obtaining the same high-quality images as the standard process. Therefore, we determined that the development time of 150 seconds was the most appropriate time. A s a result, we achieved a $20 \%$ reduction in radiation dose by using the extended process for mammographic film.

Key words: M ammography, Extended process, Micro-calcification, Shape analysis, I mage quality

別刷資料請求先：干700-8558 岡山市鹿田町2-5-1

岡山大学医学部保健学科 丸山敏則 宛 
ることのできる延長現像時間とX線量を求めた .

原画像であるX線画像においては, 微小陰影部と周 辺の背景でX線の吸収差が異なり濃度分布に差があ る.また，微小陰影部のなかでも中心部と关の辺縁に おいて濃度分布に差があると考えられる．弚こで精度 よく微小陰影像の領域を描出するために，閾值には濃 度平均值と標準偏差值の二つの值を使用し，さらに領 域の抽出を2段階で行う方法を試みた．まず微小陰影 像の辺縁より狭い領域である中心部分と陰影像の辺縁 から離れた背景部分において $3 \times 3$ の小領域を移動さ せ，小領域の濃度平均值と標準偏差值から初期閾値を 決定し，領域分割を行い，輪郭を抽出する．さらにこ の抽出した輪郭を用いて, 輪郭の内側と外側，すなわ ち陰影部と背景部に分けて再度閾值を決定した。 乥し て二值化を行い, 微小陰影像の領域を抽出し, 面積 , 周囲長，規格化面積を算出した .

次に,ファントム撮影において光れ光れの現像条件 で処理したフィルムが等しい濃度となるのに必要なX 線量を測定した .なお本実験では，自動現像機の温度 設定を $34^{\circ} \mathrm{C} ， 36^{\circ} \mathrm{C}$ した. $34^{\circ} \mathrm{C}$ 対して $36^{\circ} \mathrm{C}$ を選択 したのは, 過去の研究4)により未露光部の濃度に顕著 な増加がみられずフィルムの感度上昇が図れたためて ある.また $36^{\circ} \mathrm{C}, 90$ 秒での現像処理は，現像時間は延 長されていないが被曝低減が見込まれるため，他の延 長現像処理と同樣に $34^{\circ} \mathrm{C}$, 90秒での標準現像処理に対 する比較対象とした .

\section{1 . 使用機材}

X線撮影装置 : Toshiba Mammography Unit MGU10C (Mo target/Mo filter) (東芝・東芝メディカルシス テムズ株式会社製)

増感紙/ィルム : Kodak Min-R 2000 /Min-R 2000 自動現像機 : Kodak X-OMAT 5000RA

現像補充液 : ICM-D1

定着補充液：ICM-F1(以上コダック株式会社製) 光学顕微鏡：OlympusBH2(オリンパス株式会社製)

ディジタルカメラ：Olympus 4040ZOOM(オリンパ ス株式会社製)，1/1.8型(インチ)CCD固体撮像素子， 総画素数413万画素

ファントム : model 11 , 厚さ $4.5 \mathrm{~cm}$ (CIRS社製)，脂 肪乳腺組織等価材(成分が50\% $50 \%$ に合致) 感光計：Fuji 303(富士フイルムメディカル株式会社 製)

濃度計：PDA-15(コニカミノルタ株式会社製)

\section{2.ファントム実験}

自動現像機の現像温度 $34^{\circ} \mathrm{C}, 36^{\circ} \mathrm{C}$ と，処理時間 90 秒，150秒，210秒とを光れ組み合わせ，6種類の
現像条件についてファントムを5枚ずつ撮影した . 以 下，フィルム製造会社の推奨である3 $34^{\circ} \mathrm{C} ， 90$ 秒処理を 標準現像とする．増感紙/ィルムの組み合わせは Kodak Min-R 2000 /Min-R 2000である.

また使用したフィルムの特性曲線(露光量 - 濃度曲 線)を光センシトメトリ，すなわち感光計によって露 光したフィルムを各現像条件で処理し，濃度測定を行 うことにより求めた .

2-1 ファントム画像における微小陰影像の画像解析 本実験で使用した撮影装置はカセッテフォルダの上 にファントムを固定してあるため, フィルムカセッテ を出し入れするときにファントムか変動することはな い. $\mathrm{X}$ 線の入射角度，ファントム，フィルムの配置は 常に同じ状態で撮影されている．撮影管電圧は28kV (半価層 0.39mmアルミニウム当量)を使用した . 光し て，6 種類の現像条件で処理したファントム写真の乳 腺濃度が1.65となるように装置の管電流・時間積の值 (mAs值)を光れ光れ調整した。乳腺濃度は, 高輝度観 察器が一般に使用され, 乳腺内の組織をよりよく描出 するのに濃度值が上昇しているため, マンモグラフィ 検診精度管理中央委員会の新画像評価基準におけるス クリーン・フィルムシステムの推奨濃度の上限值1.65 を選択した ${ }^{5}$.

ファントム内には直径 $0.12 \mathrm{~mm}, 0.16 \mathrm{~mm}$, $0.20 \mathrm{~mm}, 0.23 \mathrm{~mm}, 0.27 \mathrm{~mm}, 0.35 \mathrm{~mm}$ の 6 種類の直径 を有する炭酸カルシウム $\left(\mathrm{CaCO}_{3}\right)$ の粒子が埋め込ま れ，診断における微小石灰化像を模擬している．弚れ

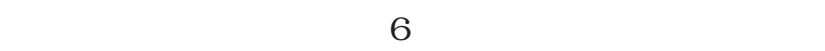
に1個と炎の周囲に 5 個が配置されている. 本研究 では6個すべてが目視によって正しい位置に明瞭に観 察できた直径 $0.23 \mathrm{~mm}$ の微小陰影像を対象とした .

フィルム試料から 6個の石灰化群の中央に位置する 微小石灰化の陰影像を顕微鏡で広大し，備え付けのデ イジタルカメラで撮影した . 微小陰影像は, すべてフ アントム内の同じ微小石灰化を写したものである .

顕微鏡のレンズとディジタルカメラの光学ズームに よって総合倍率は約10倍で画像を拡大している .この 倍率で1ピクセル当たり約 $5 \mu \mathrm{m} に$ 相当する . カメラ は顕微鏡に専用のマウントを装着し, 顕微鏡のステー ジ上に焦点が合う固定焦点て撮影した . 画像をコンピ ユータに取り込み，8ビットのグレースケール(0〜 255)に变換した．微小陰影像の辺縁より狭い領域であ る中心部と陰影像の辺緣から離れた背景部において， 3×3の小領域を 1 画素ずつ移動させ , 小領域の濃度平 均値と標準偏差值を求めた．陰影部と背景部の濃度平 均値と標準偏差值から初期閾值を決定し，二值化処理 した . 光して領域分割を行い, 輪郭を抽出した . 次に 
この抽出した輪郭を用いて, 輪郭の内側と外 側，すなわち陰影部と背景部に分けて再度閾值 を決定するという処理を行った .

本研究で用いた二值化処理を次式に示す.

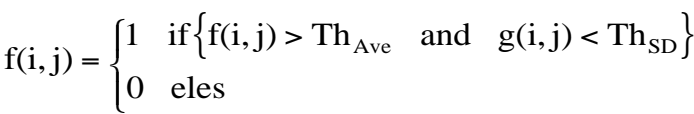

$\mathrm{f}(\mathrm{i}, \mathrm{j})$ は座標 $(\mathrm{i}, \mathrm{j})$ を中心画素とする3×3の小領 域の濃度平均值を表し, $g(i, j)$ は $(i, j)$ を中心画 素とする3×3の小領域の標準偏差值を表してい る. $T h_{\mathrm{Ave}}, \mathrm{Th}_{\mathrm{SD}}$ は濃度平均値と標準偏差值の閾 值である .

画像処理全体の手順をFig. 1に示し，二值化 における閾値の決定および画像処理の具体例を 以下1)〜10)に示した

1)Fig. 2(a)，(b)，(c)に示すように , 背景領 域として80×80ピクセル, 微小陰影像の中 心領域として32×32ピクセルの画像を切り 出す.

2)中心と背景の領域内で3×3の小領域を1画 素ずつ移動させる .

3) $3 \times 3$ の小領域の濃度平均值と標準偏差値を 求めて, 中心領域と背景領域の濃度平均值 の平均と標準偏差および標準偏差値の平均 と標準偏差を光れ光れ計算する．Fig. 2を 例にとると，中心領域の濃度平均値の平均 と標準偏差は228.1 13.4, 標準偏差值の平 均と標準偏差は11.9 \pm 8.2 となり，背景領域 の濃度平均值の平均と標準偏差は 151.6 \pm 20.8 , 標準偏差值の平均と標準偏差 は18.8土8.6となった . Fig. 2(d)，(e)は，求めた 平均と標準偏差より算出したガウス曲線である .

4)求めた平均と標準偏差から二值化のための閾值を 決定する . 濃度平均值の閾值は微小陰影部228.1 と背景部151.6の中間値である190, 標準偏差の閾 值は陰影部の平均值11.9に 2×標準偏差分 $(2 \times 8.2)$ を加えた28とした .

5) 次にFig. 2の関心領域(ROI) をFig. 3(a)のように 100×100ピクセルの画像として，3×3の小領域を 1 画素ずつ移動させ , 小領域内の濃度平均値と標準 偏差を中心画素の值とする(Fig. 3(b)) . 先に求め た閾値より，濃度平均値は190を超え，かつ標準 偏差は28未満の画素は白, 弚れ以外は黑になるよ うに二値化する(Fig. 3(c)) .

6)二值化後ラベリングし, 白の面積が最大のもの以 外は黑く塗りつ方活(Fig. 3(d)).

7)ノイズ除去のため膨張処理，収縮処理を行う . 膨

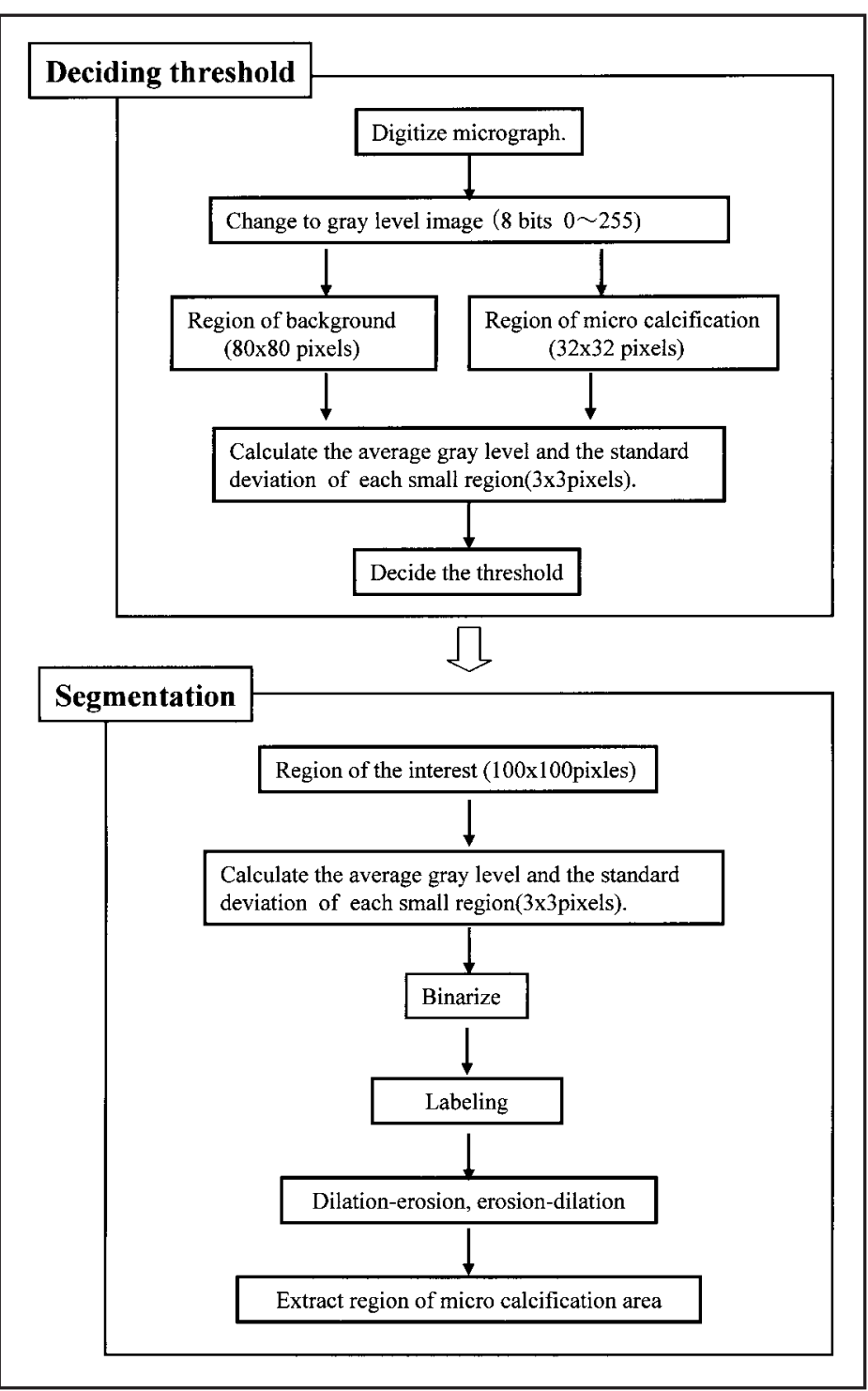

Fig. 1 Flowchart of image analysis.

張処理は，3×3のマトリクスの中心画素の值が 255ならば，周囲8近傍を255として，画像内の明 るいオブジェクトを膨張させる処理である．また 収縮処理は，マトリクスの中心画素の值が○なら ば，周囲8近傍を０として，画像内の明るいオブ ジェクトを収縮させる処理である．すべての対象 物に対して, 膨張 - 収縮 - 収縮 - 膨張の順に処理 を行う (Fig. 3(e)) .

8)領域, 輪郭抽出完了 (Fig. 3(f)).

9)原画像Fig. 3(a)に対して微小陰影像の輪郭を求め た画像Fig. 4(a)において, 輪郭線の内側(微小陰 影部)と外側(背景部)に分ける(Fig. 4(b)および (c)) .

10)分けた画像Fig. 4(b)およびFig. 4(c)に対して，2) および3)の処理を施し，中心領域と背景領域の 濃度平均值の平均と標準偏差および標準偏差値の 平均と標準偏差を关れ光れ計算する.Fig. 4(b)お 

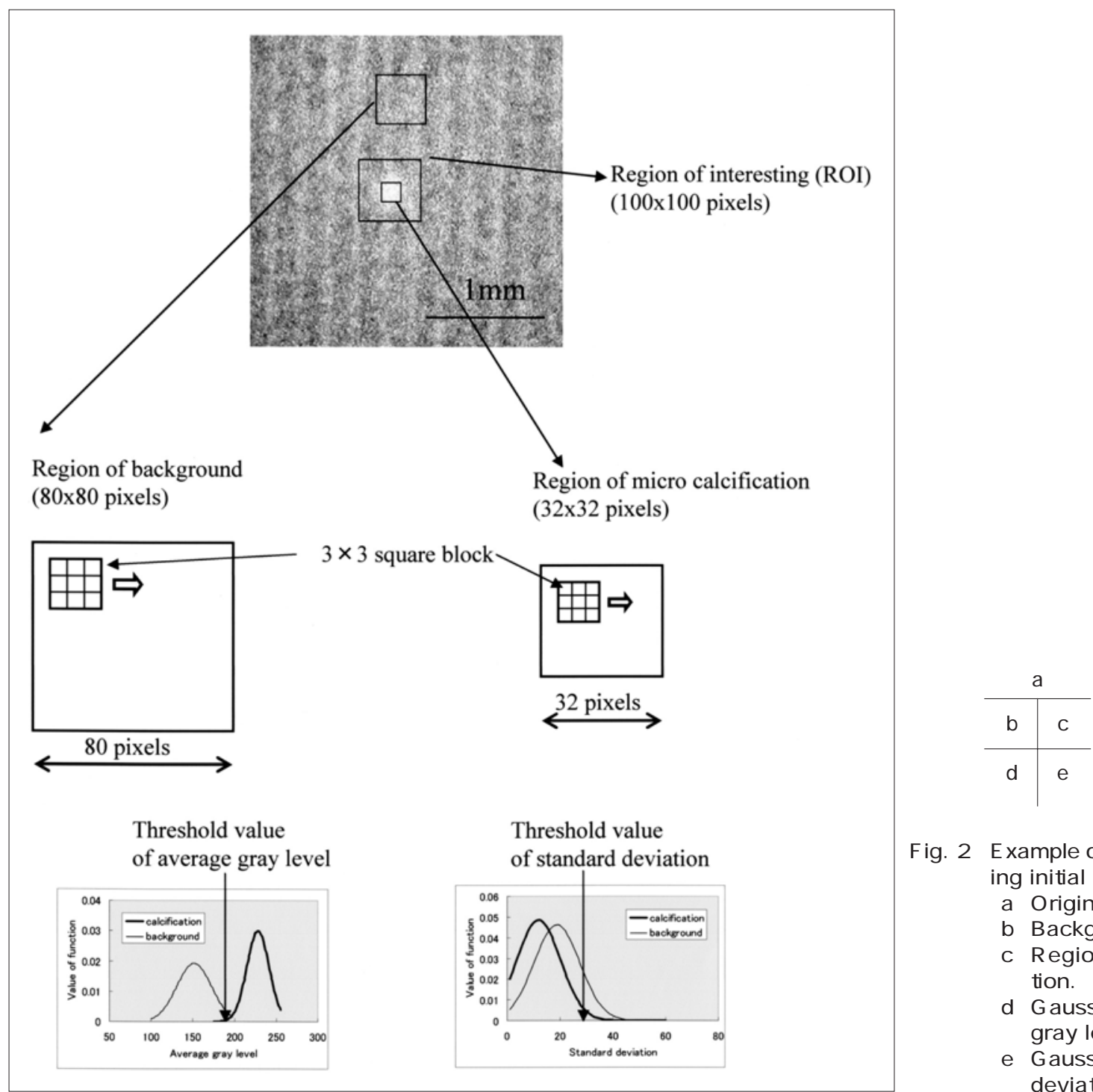

Fig. 2 Example of image for determining initial threshold.

( a) Original image.

( b) Background region.

(c) Region of micro-calcification.

(d) Gaussian curve of average gray level.

( e) Gaussian curve of standard deviation.
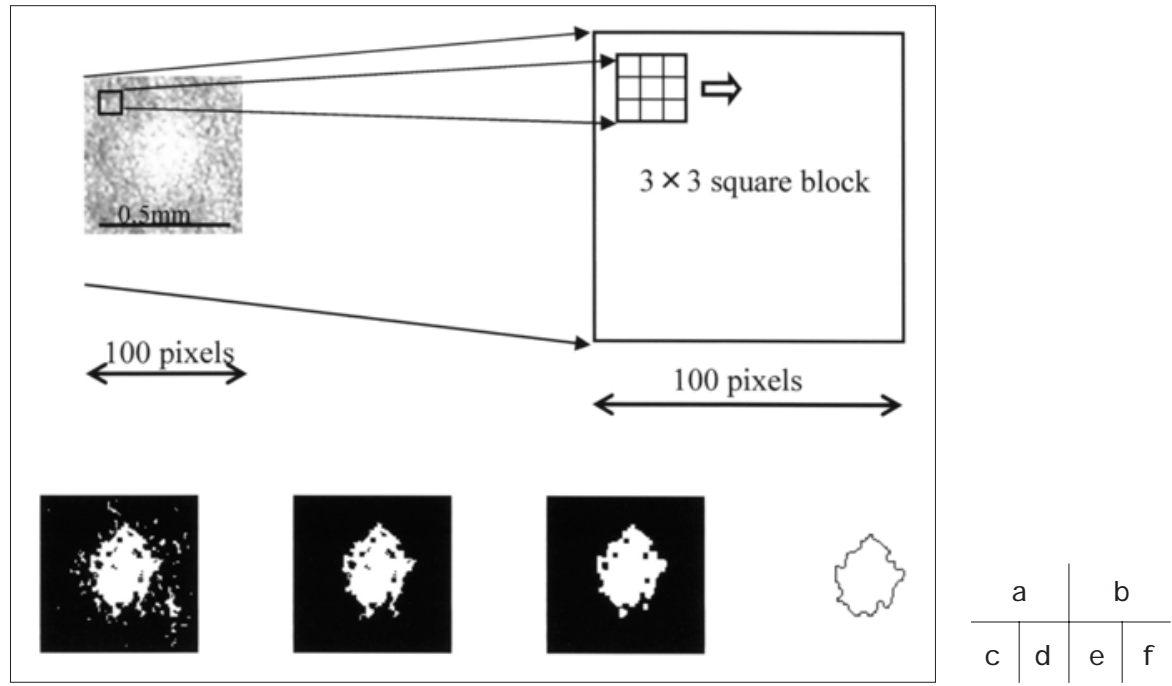

Fig. 3 Example of initial segmentation
(a) Original image same as ROI of Fig. $\not$ a)].
(b) Local block.
(c) Binary image.
( d) Binary image after labeling.
(e) Result of segmentation.
( f) Result of contour. 


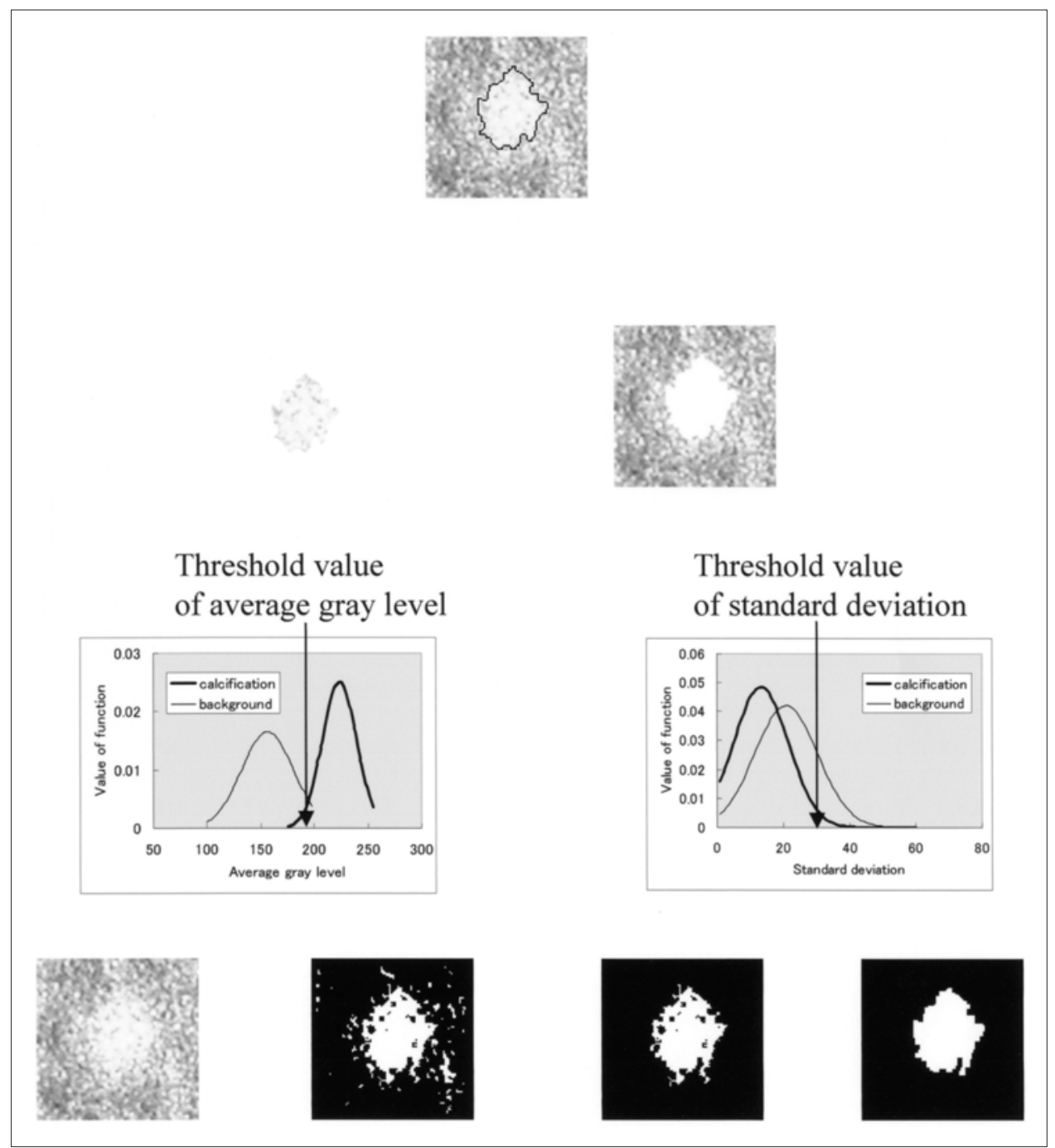

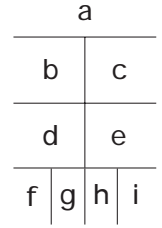

Fig. 4 Example of final segmentation.

( a) Contour detected by initial threshold.

( b) Region of micro-calcification.

(c) Background region.

(d) Gaussian curve of average gray level.

( e) Gaussian curve of standard deviation.

( f) Original imag£ same as ROI of Fig. \& a)].

( g) Binary image.

( h) Binary image after labeling.

( i) Result of segmentation.
よびFig. 4(c)において, 中心領域の濃度平均値の 平均と標準偏差は223.6土15.9, 標準偏差値の平均 と標準偏差は13.4土8.2となり, 背景領域の濃度平 均値の平均と標準偏差は156.3 24.2 , 標準偏差值 の平均と標準偏差は20.9土9.5となった . Fig. 4 (d)，(e)は求めた平均と標準偏差より算出したガ ウス曲線である．これより再度閾值を決定する． 濃度平均値の閾値は中心領域と背景領域の中間値 である190, 標準偏差は中心領域の平均値13.4に $2 \times$ 標準偏差分 $(2 \times 8.2)$ を加えた 30 とした . Fig. 4 (f) (Fig. 2(a)の関心領域と同一画像) に対して, 再 度決めた閾値で5)〜8)の処理を施し，領域を抽出 する . Fig.4(i)が，抽出された領域の結果である . 以上の画像処理を各現像条件て処理された光れ光れ 5 枚のフィルムに施し, Fig. 4(i)で示した最終的に抽 出された領域に対して, 面積, 周囲長, 規格化面積を 光れ光れ求めた . 面積は領域内の総ピクセル数, 周囲 長は縦・横方向の画素間の長さを 1 , 斜め方向を $\sqrt{2}$ と して計測したものである . 規格化面積は周囲長の2乗
を面積で除した值である．したがって，この值が大き くなると輪郭が複杂隹になり形状が崩れていることを示

している.

\section{2-2 線量測定}

ファントム撮影において異なる延長時間と現像温度 て処理したフィルムの乳腺濃度が1.65となるのに必要 な照射条件でのファントム表面への入射空中X線量を 測定した . 測定は乳房撮影精度管理マニュアルの平均 乳腺線量における入射空中X線量の測定を参考に行っ た ${ }^{6)}$. 以下，ファントム表面への入射空中X線量を照 射X線量とする

\section{3 . 結 果}

現像温度 $34^{\circ} \mathrm{C}, 36^{\circ} \mathrm{C}$, 現像処理時間90秒，150 秒，210秒とを組み合わせた 6 種類の現像条件におけ る露光量 - 濃度曲線をFig. 5に示す . 濃度はフィルム が光を透過する程度を表すもので, フィルムに入射す る光の強さを透過した光の強さで除した值を常用対数 
で表したものである．また露光量は相対露光量であ る. $34^{\circ} \mathrm{C}, 90$ 秒の標準現像処理に対する未露光部の濃 度増加は $36^{\circ} \mathrm{C} ， 210$ 秒で最大となり 0.04 であった . 露 光量 - 濃度曲線の任意の 2 点間の傾きを表す平均階調

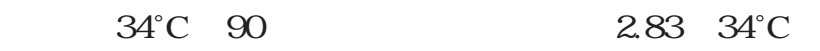
210秒処理のときが最大で3.00となった . 任意の 2 点

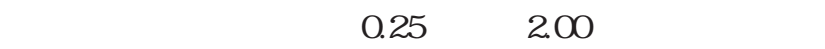
た濃度点である。

ファントム実験では乳腺濃度を1.65としてフィルム 試料を作成した . Fig. 5より，この濃度は露光量 - 濃 度曲線において直線領域にあり, 異なる現像条件でも ほぼ同等のコントラストを示しているのが分かる .こ の濃度域では, フィルムの写真濃度と8ビットのグレ 一スケールで表したディジタル画像の濃度との間には 直線関係があることを報告しており3)，ディジタル画 像はフィルム写真の濃度情報をほぼ正確に反映してい る。

次に, 各現像条件における微小陰影像の領域抽出の 処理画像 (一例)をFig. 6に示した . Fig. 6には増感紙を

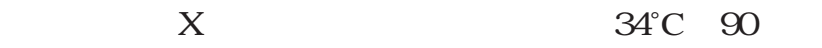
像処理を施したフィルムから得られた画像の結果も併 せて示した . 線量測定は行っていないが, 乳腺濃度 1.65を得るために，増感紙使用で $34^{\circ} \mathrm{C} ， 90$ 秒標準現像 処理の撮影時の条件での照射を80回以上行った．Fig. 6の微小陰影像は , ファントム内の同じ微小石灰化を 写したものである . すべてのファントム写真は同じ乳 腺濃度になるように作成しており，ディジタルカメラ 撮影時のシャッタースピードと絞りはほぼ一定で撮影 できた .乥して8ビットのグレースケールで表したデ イジタル画像の濃度は，増感紙を使用して撮影したす

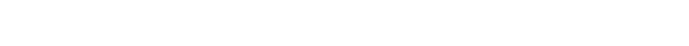

また各現像条件につき5枚ずつ処理されたファント 么写真より求めた微小陰影像の面積, 周囲長 , 規格化 面積の平均值の結果をT able 1に，照射X線量すなわち 各現像条件と形状の関係を表すグラフをFig. 7に示し た . 面積は $34^{\circ} \mathrm{C}, 36^{\circ} \mathrm{C}$ の 210 秒の延長現像処理におい ては他の現像条件に比して大きな值となった . 周囲長 は36 ${ }^{\circ} \mathrm{C} ， 150$ 秒処理より兴の值が大きくなった . 規格 化面積も概して延長時間が長くなり，照射X線量が少 なくなると值が大きくなる傾向を示した．

最後にT able 2に，各現像条件における照射時間と測 定した照射X線量，すなわちファントム表面への入射 空中X線量を示した . 同一温度て時間が延長されるほ ど，照射X線量は少なくなった．また温度が高いほど 照射X線量は少なくなった。

\section{4.考 察}

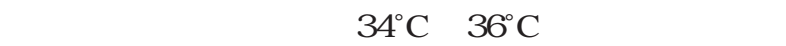

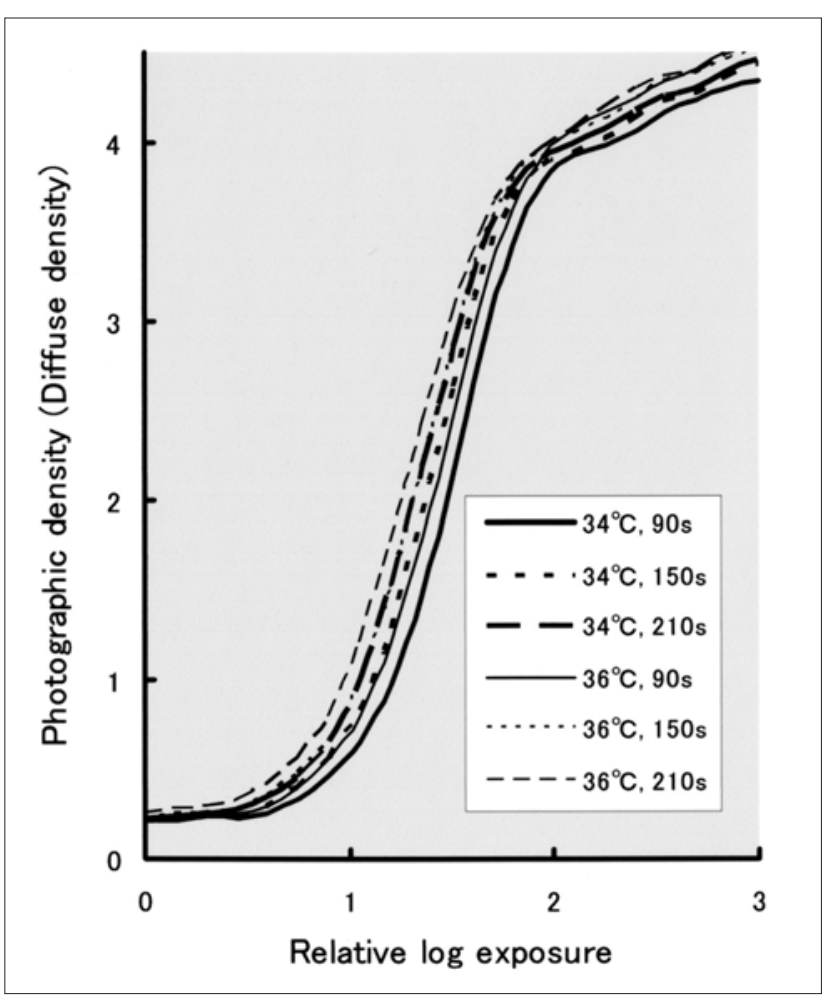

Fig. 5 Characteristic curves at developing temperature of $34^{\circ} \mathrm{C}$ and processing times of 90,150 , and $210 \mathrm{sec}$ and at $36^{\circ} \mathrm{C}$ and 90,150 , and $210 \mathrm{sec}$.

量X線照射したフィルムの150秒，210秒延長現像処理 の写真を，高線量X線照射したフィルムの34 $4^{\circ} \mathrm{C}, 90$ 秒 標準現像処理の写真と比較し，標準現像処理とほぼ同 程度の画質を保持することのできるX線量と延長現像 条件を求めた。現像温度 $34^{\circ} \mathrm{C}, 36^{\circ} \mathrm{C}$ と, 現像処理時 間90秒，150秒，210秒とを組み合わせた 6 種類の現 像条件て処理したファントム写真の微小陰影像につい ては，0.23mmの微小石灰化群の 6 個すべてが目視に よって正しい位置に明瞭に識別できている．画質評価 を客観的に行うため，微小陰影像の形状に着目して， 各現像条件につき关れ光れ 5枚のファントム写真の画 像解析を行った。微小陰影像の面積, 周囲長 , 規格化 面積を計測項目とし，5枚の平均值を求めて， $34^{\circ} \mathrm{C}$ ， 90秒標準現像処理の結果と比較した . 各項目の値が標 準現像処理した写真と比して差があることは少ない 線量による延長現像処理の影響力微小陰影像の描出す なわち画質に現れていると考えられる .

Table1およびFig. 7より，まず面積は $34^{\circ} \mathrm{C} ， 36^{\circ} \mathrm{C} の$ 210秒処理での值が他の条件よりも顕著に大きくなっ た. $34^{\circ} \mathrm{C}$, 90秒標準現像処理の面積值1457.2に対し て, $36^{\circ} \mathrm{C}, 90$ 秒処理, $34^{\circ} \mathrm{C}, 150$ 秒処理， $36^{\circ} \mathrm{C}, 150$ 秒処理では光の差は100ピクセル前後であるが，210秒 処理では200ピクセル前後と顕著に大きくなってい る . 面積は微小陰影像の大きさを端的に表す值であ 


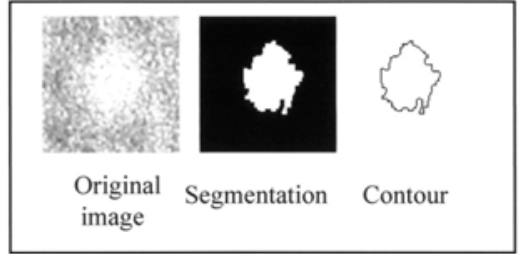

(a) $34^{\circ} \mathrm{C}, 90 \mathrm{sec}, \quad 1.96 \times 10^{-4} \mathrm{C} / \mathrm{kg}$

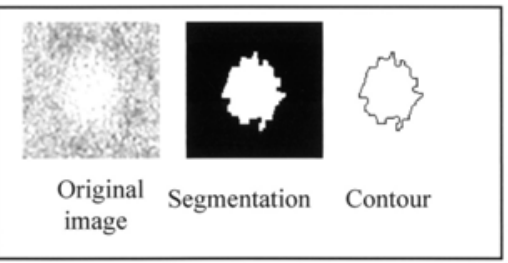

(c) $34^{\circ} \mathrm{C}, 150 \mathrm{sec} \quad 1.56 \times 10^{-4} \mathrm{C} / \mathrm{kg}$

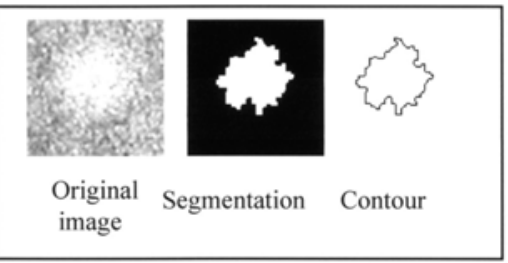

(e) $34^{\circ} \mathrm{C}, 210 \mathrm{sec} \quad 1.32 \times 10^{-4} \mathrm{C} / \mathrm{kg}$

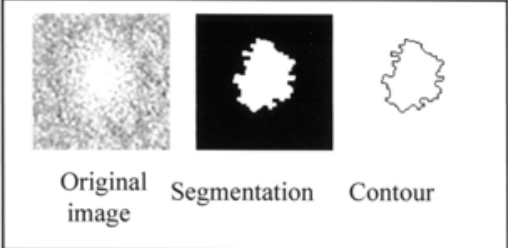

(b) $36^{\circ} \mathrm{C}, 90 \mathrm{sec} \quad 1.76 \times 10^{-4} \mathrm{C} / \mathrm{kg}$

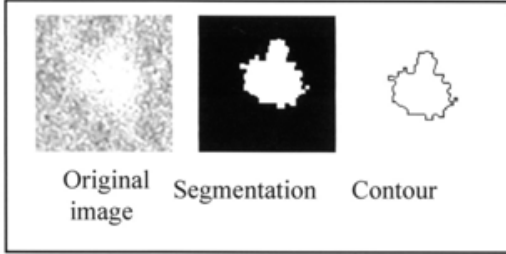

(d) $36^{\circ} \mathrm{C}, 150 \mathrm{sec} 1.46 \times 10^{-4} \mathrm{C} / \mathrm{kg}$

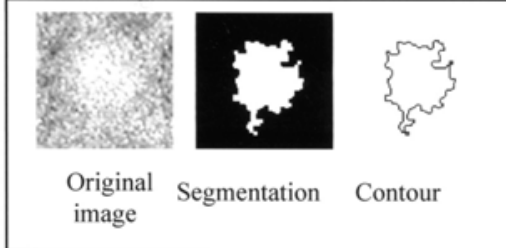

(f) $36^{\circ} \mathrm{C}, 210 \mathrm{sec} \quad 1.23 \times 10^{-4} \mathrm{C} / \mathrm{kg}$

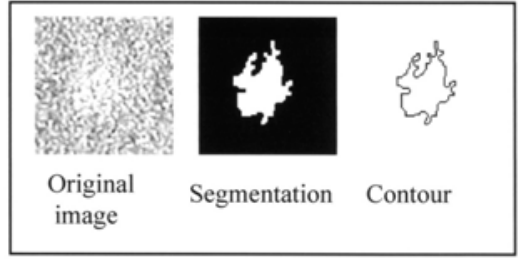

(g) $34^{\circ} \mathrm{C}, 90 \mathrm{sec}$

Fig. 6 Results of image processing.

( a) $(\mathrm{f})$ The phantom was exposed with screen

( g)The phantom was exposed without screen.

Table 1 Results of shape measurements.

\begin{tabular}{cccccc}
\hline $\begin{array}{c}\text { Phantom } \\
\text { entrance skin } \\
\text { exposure dose } \\
\left.\times 10^{-4} \mathrm{C} / \mathrm{kg}\right]\end{array}$ & $\begin{array}{c}\text { Developing } \\
\text { temperature } \\
{\left[{ }^{\circ} \mathrm{C}\right]}\end{array}$ & $\begin{array}{c}\text { Procesing } \\
\text { time } \\
{[\mathrm{sec}]}\end{array}$ & $\begin{array}{c}\text { Area } \\
{[\text { pixels }]}\end{array}$ & $\begin{array}{c}\text { Perimeter } \\
{[\text { pixels }]}\end{array}$ & $\begin{array}{c}\text { Normalized } \\
\text { area } \\
{[-]}\end{array}$ \\
\hline 1.96 & 34 & 90 & 1457.2 & 219.6 & 33.6 \\
1.76 & 36 & 90 & 1517.8 & 234.6 & 38.3 \\
1.56 & 34 & 150 & 1363.0 & 220.5 & 36.5 \\
1.46 & 36 & 150 & 1385.6 & 251.2 & 46.2 \\
1.32 & 34 & 210 & 1663.8 & 247.8 & 37.4 \\
1.23 & 36 & 210 & 1646.4 & 268.2 & 44.1 \\
\hline
\end{tabular}


る .この值が大きいことは描出が不十分となっている 可能性が高い，次に，周囲長は $36^{\circ} \mathrm{C}, 150$ 秒処理より 弚の值が大きくなった $.34^{\circ} \mathrm{C}, 36^{\circ} \mathrm{C}$ 光れ光れの 210 秒 処理の面積が , 標準現像処理の面積と200ピクセルほ ど差があるのに対して，36 ${ }^{\circ} \mathrm{C}, 150$ 秒処理と標準現像 処理との面積の差は $72 ヒ ゚ ク セ ル と 小 さ く ， 36^{\circ} \mathrm{C}, 150$ 秒処理の面積は標準現像処理と顕著な差はなかった . しかし， $36^{\circ} \mathrm{C}$, 150秒処理の周囲長か標準現像処理よ り30ピクセル以上大きくなったことは同じ大きさで抽 出された微小陰影像の輪郭に凹凸が多く形状の崩れを 表しているといえる . また, 規格化面積は概して延長 時間が長くなり，照射X線量が少なくなると值が大き くなる傾向を示した . 規格化面積は周囲長の2乗を面 積で除した值である，乥れ光れの現像条件での面積が ほぼ一定ならば，周囲長が大きくなると規格化面積も 大きくなり, 規格化面積の変化は周囲長の変化と同樣 の傾向を示すことになる . したがって面積と周囲長の 二つの值で評価すると， $36^{\circ} \mathrm{C}, 90$ 秒処理および $34^{\circ} \mathrm{C}$, 150秒処理の面積は, 標準現像処理に対して头

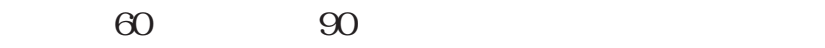
周囲長の差は10ピクセル , 1 ピクセルで , 面積 , 周囲 長ともに顕著な差はない，光して規格化面積も標準現 像処理の33.6に対して $36^{\circ} \mathrm{C}$ ，90秒処理の38.3および $34^{\circ} \mathrm{C}$, 150秒処理36.5となり顕著な差はない。これら

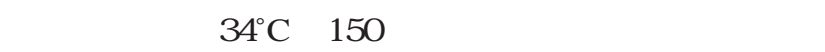
同等の画質を保持できていると考えられる．

延長時間が長くなり，照射X線量が減ると面積が大 きくなる傾向となった原因としては，延長現像におけ る感度上昇に伴う雑音の増加などが考えられる．杂倠音 の増加が粒状に影響を及ぼし，顕微鏡で拡大すること によって兴の影響が形状の変化として捉えられたので はないかと考える .

今回の実験結果より，画質を保持し，最も被曝を低 減できる現像条件は34 ${ }^{\circ} \mathrm{C}, 150$ 秒の延長現像処理であ つた . 产の場合, 標準現像処理と等しい乳腺濃度を得 るための照射 X 線量は, $34^{\circ} \mathrm{C}, 150$ 秒の延長現像処理

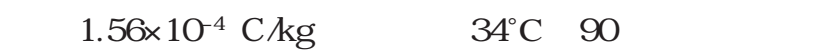
処理における1.96×10-4 [C kg]に比して，20.4\%の照射 X線量の低減が図れることが明らかになった .

なお本研究では, 脂肪乳腺組織の成分割合か $50 \% /$ $50 \%$ である1種類のファントムに対して実験を行った ものである . 乳腺組織の含有率が異なれば画質を保持 できる延長現像時間も变化し，照射X線量の低減率も 異なってくると予想される .

今回，画質評価として用いた画像解析において，小 領域の濃度平均值と標準偏差值を用いて，2段階の閾 值設定を行って領域を抽出した . ファントム画像にお ける微小陰影像の画像解析の処理例で示したように，

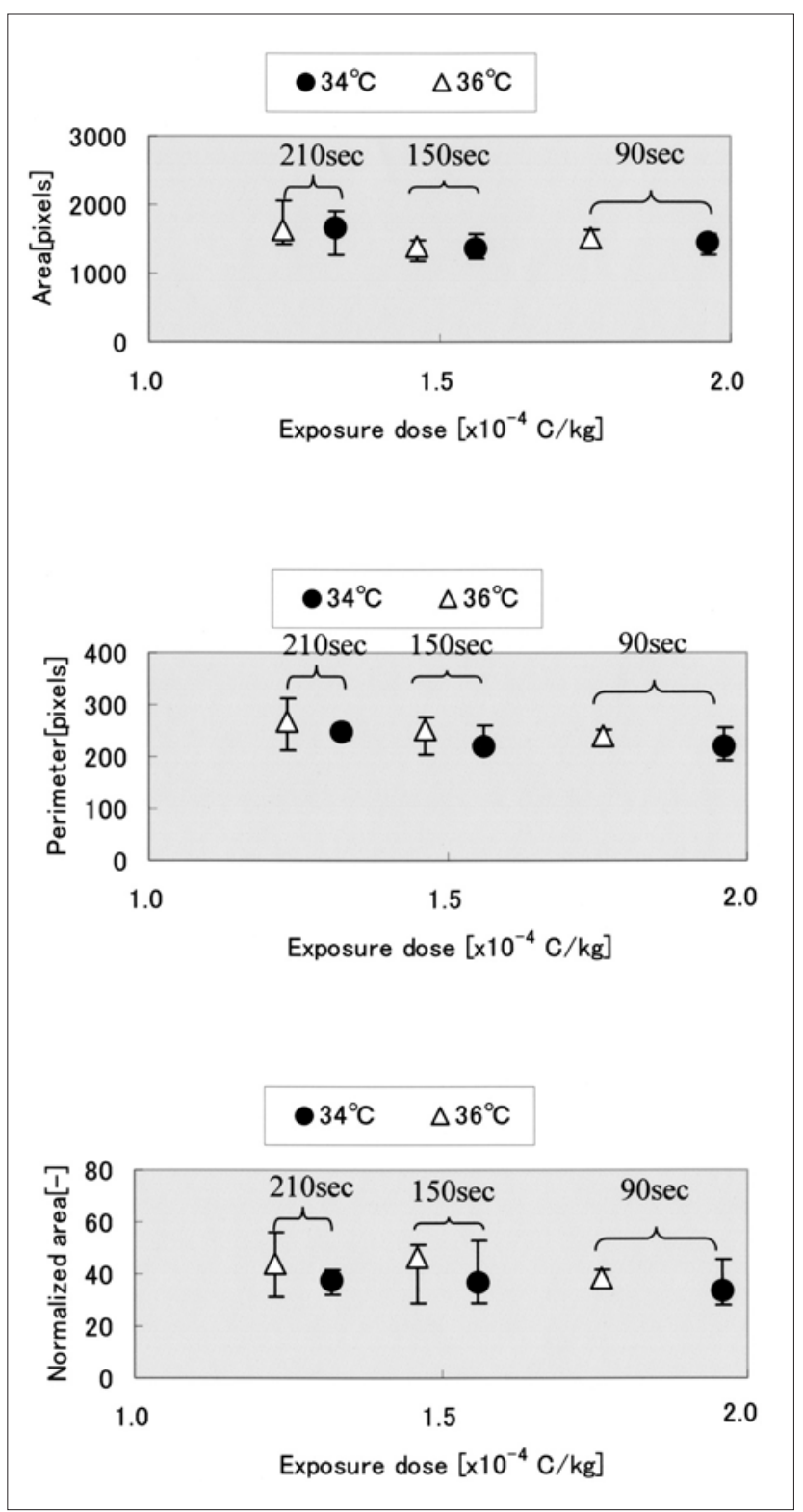

Fig. 7 Relationship between phantom entrance exposure dose and shape measurements of micro-calcification.

( a)Area( b) Perimeter( c)Normalized area Error bars represent maximum and minimum values.

a

Table 2 Phantom entrance exposure dose for six processing conditions.

\begin{tabular}{ccc}
\hline $\begin{array}{c}\text { Developinng } \\
\text { temperature } \\
{\left[{ }^{\circ} \mathrm{C}\right]}\end{array}$ & $\begin{array}{c}\text { Processing } \\
\text { time } \\
{[\mathrm{sec}]}\end{array}$ & $\begin{array}{c}\text { Phantom } \\
\text { entrance skin } \\
\text { exposure dose } \\
\left.\times 10^{-4} \mathrm{C} / \mathrm{kg}\right]\end{array}$ \\
\hline 34 & 90 & 1.96 \\
36 & 90 & 1.76 \\
34 & 150 & 1.56 \\
36 & 150 & 1.46 \\
34 & 210 & 1.32 \\
36 & 210 & 1.23 \\
\hline
\end{tabular}


最初に微小陰影像の中心部の濃度から求めた標準偏差 值の平均11.9より初期輪郭の内側で求めた標準偏差值 の平均は13.4と大きくなり, 微小陰影像の中心部に比 べて微小陰影像の辺縁付近での濃度のばらつきが大き いことを示している．したがって，中心部の濃度情報 のみて閾値を決定して微小陰影像の領域を抽出するよ り，辺縁に近い領域の濃度情報を含めて再度閾值を決 定した本手法は，X線写真の情報を反映した微小陰影 像の領域力抽出できていると考えられる．乥して，目 視では捉えることができなかった低線量撮影，延長現 像における画質の差を形状計測によって確認すること ができた . また過去に報告した ファイルでは確認できなかった画質の差が二次元的な 形状評価を行った本手法により確認することができ， 本手法が客観的な画質評価に有効であったといえる．

本研究では, 温度を上昇させることによってもフィ ルムの感度が上昇し，被曝を低減することができるこ とに着目して，34 $\mathrm{C}$ に対して $36^{\circ} \mathrm{C}$ を選択して実験を 行った . Table2に示すように, 温度上昇による照射X 線量の低減は大きい，また延長時間の短縮を図ること ができる．現像条件によって被曝低減を考える場合， 各現像温度での画質が保持できる延長現像時間の限界 値を調べることは重要である．

また今回の実験て撮影したフィルムにはブッキー撮 影によるグリッドラインが見えるものがあつた . 処理 したフィルムはグリッドラインの影響の少ないものを 選んだが , グリッドラインを除去する画像処理のアル ゴリズムを検討するのが今後の課題の一つとなる .

最後に, 本研究では可能な限り実物に近し状態とし て, 増感紙を除去した状態て撮影し, 微小陰影像の形 状や面積を把握しようと試みた。しいし本実験で作成 したフィルムの乳腺濃度1.65を得るためには, 増感紙 を使用し，34 ${ }^{\circ} \mathrm{C}$, 90秒の標準現像処理の撮影時の照射 を80回以上行わなければならなかった . また増感紙な して撮影したフィルムの画像は, Fig. 6(g)に示すよう に増感紙使用に比べてコントラストが低く, 微小陰影 部と周辺の濃度差が小さい画像となった . 増感紙を使 用して撮影したフィルムと同じ画像処理を行うと，領 域抽出か容易ではなかった . 機器への負担が非常に大 きかったため 3 枚の試料の結果となるが, 面積, 周囲
長，規格化面積の平均値は，1454.7ピクセル，315.0 ピクセル，67.61となった . 面積は領域内の総ピクセ ル数, 周囲長は縦・横方向の画素間の長さを 1 , 斜め

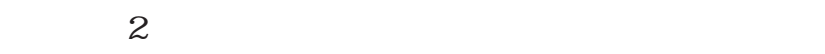
陰影像の形状はかなり崩れたものとなった .このよう なコントラストの低い画像に対しては画像処理のアル ゴリズムを検討する必要があると考えられる．

\section{5 . 結 語}

本研究は, 低線量て撮影したマンモグラフィ用フィ ルムに延長現像処理を施すことにより，高線量て撮影 し標準現像処理を施したものと同程度の画質を得るた めの現像条件と照射 $X$ 線量について検討したものであ る、画質を客観的に評価するために，形状に着目した 画像解析による評価法を提案した . 微小陰影像の形状 解析により画質を評価したところ，一方向の濃度プロ ファイルでは確認できなかった現像条件の違いによる 画質の差を，二次元的な形状解析によって確認するこ とができ，この手法が有効であることか明らかになっ た. 弚の結果，延長現像処理によって被曝低減が可能 となり，延長現像処理は極めて有用な撮影方法である ことが明らかになった .

以下に光の内容を要約する .

延長現像処理した乳房撮影用フィルムの画質を, 微 小石灰化陰影像の形状に着目して , 面積 , 周囲長 , 規 格化面積によって客観的に評価した . 実験として, 自 動現像機の現像温度を $34^{\circ} \mathrm{C}, 36^{\circ} \mathrm{C}$, 低線量X線照射し たフィルムの150秒，210秒延長現像処理の写真を，高 線量 X線照射したフィルムの90秒標準現像処理の写真 と比較し, 標準現像処理とほぼ同程度の画質を保持す ることのできるX線量と延長現像条件を求めた，弚の 結果，34 ${ }^{\circ} \mathrm{C}, 90$ 秒の標準現像処理とほほ同程度の画質 を保持し，被曝を最も低減できるのは，34 ${ }^{\circ} \mathrm{C}, 150$ 秒 の延長現像処理であり，照射X線量は，1.56×10-4 [C kg] となった. 乥して $34^{\circ} \mathrm{C}$, 90秒の標隼現像処理に おける照射X線量1.96 $\times 10^{-4}[\mathrm{C} / \mathrm{kg}]$ に比して，20.4\%の 照射 $X$ 線量の低減が図れることが明らかになった .

臨床に応用するうえで，脂肪乳腺組織の成分割合 に対応した照射X線量と延長現像条件を求めることが 臨床に応用するうえで今後の検討課題であると考える．

\section{参考文献}

1) http://www .asahi .com/heal th/cancer /07.html

2) がん検診に関する検討会 : 乳がん検診及び子宮がん検診の 見直しについて がん検診に関する検討会中間報告 . (2004) .

3) 丸山敏則, 山本秀樹 : 延長現像におけるマンモグラフィ用 フィルムの画質評価 .日放技学誌，60(11)，701-710， (2004) .

4) 丸山敏則, 後藤佐知子, 東 義晴, 他 : マンモグラフィ用 フィルムにおけるextended-cycle processの基礎的研究-コ ントラスト，相対感度 - . 日放技学誌，53(11)，16971704, (1997).

5) http://www .mammography.jp/mammo/oshirase4-1.html

6) 日本放射線技術学会放射線撮影分科会 : 乳房撮影精度管理 マニュアル（社)日本放射線技術学会, 京都, (1997). 
| | | | | | | | | | | | | | | | | | | | | | | | | | | | | | | | | | | | | | | | | | | | | | | | | | | | | | | | | | | | | | | | | | | |

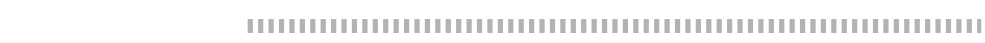

Fig. 1 画像処理の流れ図

Fig. 2 初期閾值決定例
(a) 原画像
(b)背景領域
(c)微小石灰化領域
(d)濃度平均值(グレーレベル)のガウス曲線
(e)標準偏差值のガウス曲線

Fig. 3 初期領域分割の例
(a) 原画像 (Fig. 2(a)のROIと同じ)
(b) 局所ブロック
(c)二值化像
(d)ラベリング後の二值化像
(e)領域分割の結果
( $f$ )輪郭

Fig. 4 最終領域分割の決定例
(a)初期閾値で決定された輪郭
(b)微小石灰化領域
(c)背景領域
(d)濃度平均值 (グレーレベル)のガウス曲線
(e)標準偏差値のガウス曲線
(f) 原画像 (Fig. 2(a)のROIと同じ)
(g)二值化像
(h)ラベリング後の二值化像
(i)領域分割の結果

Fig. 5 現像温度 $34^{\circ} \mathrm{C}$, 処理時間 $90,150,210$ 秒と， $36^{\circ} \mathrm{C}, 90,150,210$ 秒における特性曲線

Fig. 6 画像処理の結果(一例)
(a)〜 (f)増感紙を使用して撮影されたファントム
(g)増感紙を使用せずに撮影されたファントム

Fig. 7 ファントム表面への入射空中X線量と微小石灰化陰影の形状の関係
(a)面積，(b)周囲長，(c)規格化面積
エラーバーは最大値と最小值を示す．

Table 1 形状計測の結果

Table 26 種類の現像条件におけるファントム表面への入射空中X線量 